ISSN: 1110-5623 (Print) - 2090-0570 (Online)

\title{
SEMEN QUALITY AND HEMATOLOGICAL PARAMETERS OF SINA COCKS FED ATRIPEX NUMMULARIA LEAVES MEAL UNDER DESERT CONDITIONS
}

\section{K.Emam ${ }^{*}$, K. R. S.; Amal M. Hassan'; Morsy $^{2}$, A.S and Abd El-Galil ${ }^{3}$}

${ }^{1}$ Anim. and poult. prod. dep. , Fac. of envir. and biological agric. and food processing, Beni-suef Univ. Egypt. ${ }^{2}$ Anim.and Poult. Phys. Dep., Desert Res. Cen., Egypt.

${ }^{3}$ Anim. and Poult. Nutr. Dep., Desert Res. Cen., Egypt.

Corresponding author: K.R.S. Emam ${ }^{1}$ Email: khamis.rifai@agr.bsu.edu.eg

$$
\text { Received: } 06 / 09 \text { /2017 Accepted: 31/10/2017 }
$$

\begin{abstract}
This study aimed to investigate the effect of using different levels of Atripex nummularia leaves meal (ALM) on semen quality, some blood parameters and hormonal aspects of Sina cocks under South Sinai conditions. A total number of 36 Sina cocks aged 22 weeks were used. Cocks were randomly separated into four equal groups. The $1^{\text {st }}$ group was fed a basal diet as a control (0\% ALM), while, the $2^{\text {nd }}, 3^{\text {rd }}$ and $4^{\text {th }}$ groups were fed diets comprising 4, 8 and $12 \%$ ALM, respectively.

The result reviled that cocks fed dietary $12 \%$ ALM exhibited decrease $(\mathrm{P}<0.05)$ in ejaculate volume, sperm concentration, total sperm output, sperm motility, total motile sperm, semen quality factor and hydrogen ion $(\mathrm{pH})$ compared to control group. Moreover, cocks fed dietary $12 \%$ ALM showed decreased $(\mathrm{P}<0.05)$ the values of Red blood cells, hemoglobin and mean corpuscular hemoglobin concentration concentrations as compared to control diet. However, cocks fed dietary $12 \%$ ALM showed significantly increased mean corpuscular volume as compared to other fed dietary 0,4 and $8 \%$ ALM. Albumin, cholesterol, triglycerides, alanine transaminase $(\mathrm{ALT})$ and aspartic transaminase $(\mathrm{AST})$ levels decreased $(\mathrm{P}<0.05)$ when birds fed dietary $12 \%$ ALM, however, this diminishing was $(\mathrm{P}>0.05)$ between all other levels of ALM compared with the control diet. Potassium, chloride and calcium levels were higher $(\mathrm{P}<0.05)$ for birds fed $12 \%$ ALM compared with the control diet. However, phosphorus level was lower in the cocks fed dietary all levels of dietary ALM compared to cocks fed control diet. However, the differences was significantly $(\mathrm{P}<0.05)$ only at the level of $12 \%$ ALM. Aldosterone and tri-iodothyronine hormones were decreased $(\mathrm{P}<0.05)$ in the cocks fed $12 \%$ ALM than that of control group. In conclusion, under South Sinai conditions, Atriplex nummularia leaves meal could be utilized safety in Sina cocks diet up to $8 \%$ without adverse or serious effects on the semen quality characteristics and some blood constituents.
\end{abstract}

Key words:Atriplex nummularia leaves, hematological parameters, semen quality, Sina cocks. 


\section{INTRODUCTION}

Atriplex nummularia an ever green shrub, widely circulated and refined in Egypt along the Mediterranean zone (El-Shaer, 2005 and Shawket and Ibrahim, 2013). Atriplex so called is identified to be tolerant to drought and salinity. It is high in crude protein, crude fiber and ash but relatively low in carbohydrates (El-Shaer, 2004 and Ben salem et al., 2005). South Sinai is hyper arid region with salt affected natural resources. So, feed resources in the area are that represent one of the main obstacles for animal production development in the aria. Atriplex nummularia has great potentialities since it is known to be tolerant to salinity (El Shaer, 2010). However, it is poor in energy and around $65 \%$ of nitrogen is non- protein nitrogen. The high salt level in Atriplex limits its intake and digestion (Hassan, 2009). Also Atriplex species contain some secondary metabolites as condensed tannins which may restrict feed intake and lead to a negative impact on animal performance (Mansoori and Acamovic, 1997 and Ben Salem et al., 2010).

Hematological parameters and minerals are changed by drinking saline water (Fayez et al., 1994). The deleterious effect of saline water on blood constituents and reproductive performance of cocks were restricted researches (Hadziosmanovic et al., 1997). The assessment of semen characteristics of poultry gives an excellent indicator of their reproductive potential and has been reported to be a chief determinant of fertility and subsequent hatchability of eggs (Peters et al., 2004). An increased percentage of morphologically modified sperm cells may result in impaired fertility (Saacke et al., 2000). A decrease in fertility and the occurrence of pathological sperm cells may be markedly influenced not only by chemical and physical factors but also, and above all, by stress, salinity and age of males (Jarinkovičova et al., 2012). Salinity and heat stress are a problem commonly found in Egypt. Several researchers described that salinity and heat stress led to unsafe effects on hematological parameters and semen quality (Sturkie, 1986; Mashaly et al., 2004; Morsy et al., 2012; Amal, 2013 and Abd El-Galil et al., 2014).

Afraid studies were troubled with the effect of Atriplex nummularia leaves meal on the blood components and semen quality of cocks. Abd El-Galil and Khidr (2001) used successively and safety of the formulate diet for rabbits to include Atriplex nummularia leaves meal up to $25 \%$ without unfavorably affecting their performance. Under arid conditions, we can be used up to $8 \%$ Atriplex nummularia leaves meal as a source of substitute feed resources of laying hens without adverse effects on physiological and productive performance (Abd ElGalil et al., 2014). Under South Sinai conditions, natural saline water (6000 ppm TDS) could not tolerate by cocks as directed by negative effects shown on blood constituents and semen quality, conversely, no toxic effect was found with using saline water that contain 2000 or $4000 \mathrm{ppm}$ TDS (Amal, 2013). Then, this study designed to the effect of using different levels of Atripex nummularia leaves meal on semen quality, hematobiochemical parameters, hormonal aspects and mineral parameters of Sina cocks under South Sinai conditions.

MATERIALS AND METHODS

The present study was carried out at South Sinai Experimental Research 
Atriplex nummularia leaves, hematological parameters, semen quality, Sina cocks.

Station (Ras-Suder City) which fits to the Desert Research Center. This experiment was started from June to September 2012 and aimed to the effect of using different levels of Atripex nummularia leaves meal on semen quality, hemato-biochemical parameters, hormonal aspects and mineral parameters of Sina cocks under South Sinai conditions.

A total number of 36 Sina cocks aged 22 weeks and body weight of $1956.7 \pm 29.0$ $\mathrm{g}$ were used until 34 week of age. Cocks were randomly divided into four equal groups (9 cocks of each). The $1^{\text {st }}$ group was fed a basal diet (0\% of Atriplex nummularia leaves meal) as a control group, whereas, the $2^{\text {nd }}, 3^{\text {rd }}$ and $4^{\text {th }}$ groups were fed diets containing 4, 8 and $12 \%$ Atriplex nummularia leaves meal, respectively.

The diets (Table 1) were formulated in granular form according to NRC (1994) and were iso-nitrogenous (16\% CP) and iso-caloric (2700 kcal ME/kg). Feed was presented ad libitum and fresh water was available.

The proximate chemical analysis of Atriplex nummularia leaves and mineral content were $20.1 \%$ crude protein, 4.01 crude fiber, $18.4 \%$ ash, $0.89 \%$ magnesium, $1.5 \%$ calcium, $0.35 \%$ phosphorus, $2.9 \%$ sodium, $3.5 \%$ potassium, $20.4 \mathrm{ppm}$ iron, $26.5 \mathrm{ppm}$ copper, $51.8 \mathrm{ppm}$ zinc and $75.0 \mathrm{ppm}$ manganese.

All groups were reared under hot month's condition. Indoor maximum ambient temperature, relative humidity and temperature-humidity index were $36.7^{\circ} \mathrm{C}$, $25.5 \%$ and 31.4 , respectively.

Cocks were exposed to natural day-light and provided with artificial light to increase the day light length until reaching $16 \mathrm{~h} /$ day and it kept constant until the end of experiment. Birds were kept under the same managerial and hygienic conditions. Cocks were healthy and observed against diseases and treated with antibiotics and vaccines.

Semen was collected from 8 cocks / group which randomly selected using the massages method. The ejaculate volume was determined to the nearest $0.01 \mathrm{ml}$ using tuberculin syringe. Sperm concentration was determined by using Thomes-Zeis haemocytometer (Kalamah et al., 2000). Total sperm output was calculated by multiplying ejaculate volume and spermatozoa concentration. Percentage of live and abnormal sperms were determined after staining with eosine and nigrosine (Blom, 1950), then calculated as a percentage out of randomly chosen 100 sperm counted. Percentage of motile sperm was estimated a phase-contrast microscope (Melrose and Laing, 1970). Total number of motile sperm (TMS) calculated by multiplying percentage of motile sperm and total sperm output. Semen quality factor (SQF) $=$ sperm concentration $\times$ ejaculate volume $\times$ live spermatozoa) / 100. Hydrogen ion concentration $(\mathrm{pH})$ of semen was determined directly after collection using $\mathrm{pH}$ paper.

Blood samples were randomly withdrawn from the wing vein into tube containing EDTA to examine immediately red blood cells counted in blood under the microscope by means of hemocytometer and hemoglobin concentration according to Jaime (2000). Hematocrite (\%) was estimated using microhematocrit tubes by wintrobe methods. Mean corpuscular volume (MCV), mean corpuscular hemoglobin $(\mathrm{MCH})$ and mean corpuscular hemoglobin concentration (MCHC) were calculated as follows:

$\mathrm{MCH}$ (in pico gram, pg) $=(\mathrm{Hb}$ content $\mathrm{g} / \mathrm{dl} \times 10) / \mathrm{RBCs}$ in million 
Emam $^{1^{*}}$, K. R. S.et al.

$\mathrm{MCHC}(\%)=(\mathrm{Hb}$ content $\times 100) / \mathrm{Ht} \%$ $\mathrm{MCV}$ (in femto liter, fl) $=(\mathrm{Ht} \% \times 10) /$ RBCs in million

Plasma was collected by using centrifugation for 15 minutes at $3000 \mathrm{rpm}$ and it stored at $-20{ }^{\circ} \mathrm{C}$ until analysis. Total protein, albumin, cholesterol, triglycerides, alanine transaminase, aspartic transaminase, total antioxidant capacity. Serum was collected to analysis sodium, potassium, calcium, phosphorus, chloride and magnesium. All samples were determined calorimetrically by using commercial kits. Globulin was calculated by the difference between total protein and albumin.

Tri-iodothronine, aldosterone and testosterone hormones were determined by ELISA method.

Statistical analysis was carried out using General Linear Model (GLM) procedures by SAS (2004) using simple one-way analysis of variance according to this model:

$\mathrm{Y}_{\mathrm{ij}}=\mu+\mathrm{T}_{\mathrm{i}}+\mathrm{e}_{\mathrm{ij}}$

Where: $Y_{i j}=$ any observation of $i^{\text {th }}$ cock within $j^{\text {th }}$ group, $\mu=$ overall mean, $T_{i}=$ effect of $i^{\text {th }}$ group (i: 1-4), $\mathrm{e}_{\mathrm{ij}}=$ experimental error.

Significant differences among treatment means were tested using Duncan multiple range test (Duncan, 1955).

\section{RESULTS AND DISCUSSIONS}

\section{Semen quality}

Table (3) demonstrated that cocks fed dietary $12 \%$ ALM exhibited decrease $(\mathrm{P}<0.05)$ in ejaculate volume, sperm concentration, total sperm output, sperm motility, total motile sperm, semen quality factor and hydrogen ion $(\mathrm{pH})$ by 51.1, 25.6, 63.6, 18.3, 70.3, 65.2 and 2.4 $\%$, respectively as compared to control group. However, no significant differences $\quad(\mathrm{P}>0.05) \quad$ were observed between the cocks fed other dietary ALM levels. Dead sperm and sperm abnormalities \% were insignificantly $(\mathrm{P}>0.05)$ increased in the cocks fed $12 \%$ ALM when compared to other groups. However, testosterone hormone was insignificantly $(\mathrm{P}>0.05)$ decreased in the cocks fed $12 \%$ ALM by $20.8 \%$ as compared to control group (Figure 1).

Lower semen quality in the cocks fed 12 $\%$ ALM may reflect an adverse effect of high saline content on the spermatogenic process by cause a stress on the pituitary gland and hence led to alteration in the gonadotropins releasing cells activity which controls the androgenic secretion by testes (Amal et al., 2013). Salinity may cause severe degeneration of testes tissue and aggregation of RBC'S in central vein and in the sinusoids, aggregation of lymphocytes, necrosis of tubular epithelium, severe hemorrhage, severs degeneration of the kidney tissues (Ezzat et al., 2007).

On the other hand, the cocks fed dietary 4 or dietary $8 \%$ ALM showed no delirious effect on the semen quality traits when compared in the cocks fed dietary $12 \%$ ALM and there were no significant differences $(\mathrm{P}>0.05)$ between the cocks fed diets containing 8 or $4 \%$ ALM and the cocks fed $0 \%$ ALM (control group), indicating that the cocks fed diets containing 4 or $8 \%$ ALM was capable to tolerate the salinity level. Where, under high saline stress conditions (12\% ALM), the electrolytes system of cocks was not capable to maintaining normal homeostasis and hence it negatively effect on semen quality characteristics (Abd El-Galil et al., 2014; Morsy et al., 2012 and Amal, 2013).

\section{Hematological parameters}

The results of Table (4) revealed that cocks fed dietary $12 \%$ ALM showed decreased $(\mathrm{P}<0.05)$ the values of RBC's , 
Atriplex nummularia leaves, hematological parameters, semen quality, Sina cocks.

$\mathrm{Hb}$ and $\mathrm{MCHC}$ concentrations as compared to others fed control diet. However, cocks fed $12 \%$ ALM showed significantly $(\mathrm{P}<0.05)$ increased $\mathrm{MCV}$ as compared to diets contain 0,4 and $8 \%$ ALM. No significant $(\mathrm{P}>0.05)$ differences between treatments in $\mathrm{Ht} \%$ and $\mathrm{MCH}$. Also, no significant differences between the cocks fed dietaries 8,4 and $0 \%$ ALM in hematological parameters. This decrease in $\mathrm{RBCs}$ count, $\mathrm{Hb}$ and $\mathrm{MCHC}$ concentrations or increase in $\mathrm{MCV}$ of cocks fed salt plant $12 \%$ ALM might be due to increased water intake that may be caused hemodilution (Assad et al., 1997; Abd El-Galil et al., 2014; Morsy et al., 2012). On the other hand, Amal (2013) reported that salt intake caused varying degrees of anhydremia resulting in an elevation of specific gravity and hematocrit value in the blood. Others researchers found a decrease in $\mathrm{Hb}$ of different species of farm animals fed salt plants (El-Hawy, 2013; Kawashti et al., 1983; Hussein et al., 1990 and Ibrahim, 1995).

\section{Biochemical parameters}

Cocks fed dietary $12 \%$ ALM showed decreased $\quad(\mathrm{P}<0.05) \quad$ albumin concentration as compared to the cocks fed $0 \%$ ALM (Table 5). However, cocks fed $12 \%$ ALM showed insignificantly decreased $(\mathrm{P}>0.05)$ in total protein and globulin concentrations as compared to other treatments. Total protein and its fractions, albumin and globulin have a great importance as decent indicators of nutritional status (Fayed et al., 2010 and Shaker et al., 2014). It is well known that albumin is synthesized only in the liver. So the decrease in albumin concentration in the cocks of $12 \%$ ALM might reflect practical damage of liver function (Latimer et al., 2003).
Cholesterol and triglycerides levels were significantly decreased in the diet containing $12 \%$ ALM by 19.9 and 22.6 $\%$, respectively as compared to $0 \%$ ALM. These results approve with the results of Abd El-Galil et al. (2014) noted a decrease in cholesterol level as a result of high salt intake. They declared that this decrease may be triggered by the antinutritional factors in Atriplex nummularia leaves meal that affected lipids profile indirectly. Tannins play a deep role in lipid digestibility by complexion with fatty acids (Romero et al., 2000).

Alanin transaminase (ALT) and aspartic transaminase (AST) were significantly increased in the cocks fed $12 \%$ ALM by 26.5 and $25.0 \%$, respectively than that of the control group. Activities of liver enzymes are conventionally used for diagnostic hepatic functions and damage (Lassard et al., 1986; Craig et al., 1991 and Abd El-Galil et al., 2014). This results may indicates that salt load by feeding Atriplex nummularia leaves meal (12\%) did extremely affect the liver functions and in turn the animal's health.

However, no significant differences $(\mathrm{P}>0.05)$ between treatments in total antioxidant capacity (TAC) concentration.

\section{Minerals parameters}

Potassium level was higher $(\mathrm{P}<0.05)$ in the cocks of dietary $12 \%$ ALM by 22.2 and $19.5 \%$ compared with others fed diets contain 4 and $0 \%$ ALM, respectively (Table 6). Chloride level was higher $(\mathrm{P}<0.05)$ in the cocks fed dietary $12 \%$ ALM by $14.0 \%$ as compared to 0 $\%$ ALM. Calcium level was significantly higher in the cocks of $12 \%$ ALM by 33.9 $\%$ compared with $0 \%$ group. However, phosphorus level was lower $(\mathrm{P}<0.05)$ in the cocks fed $12 \%$ ALM by $15.0 \%$ as compared to cocks fed control diet 
Emam $^{1^{*}}$, K. R. S.et al.

(Table 6). The decreased phosphorus level may be attributed to their reciprocal reverse relationship as the increased blood calcium level resulted in increased parathyroid hormone secretion which inhibits the renal tubules reabsorption of phosphorus (Abd El-Galil et al., 2014).

However, no significant differences between treatments in sodium and magnesium levels. Also, no significant $(\mathrm{P}>0.05)$ differences between the cocks fed diets contain 8,4 and $0 \%$ ALM in mineral parameters. Minerals happen in body fluids and tissues as electrolytes, alarmed with the maintenance of osmotic pressure, acid-base balance, membrane permeability and tissue irritability (Milne, 1996 and Underwood and Suttle, 1999). The increase of some minerals in blood might attributed to high tannins content in Atriplex nummularia leaves meal were found to be worrying the absorption of minerals through the intestinal tract (Mansoori and Acamovic, 1997).

\section{Aldosterone and Tri-iodothyronine hormones}

Aldosterone hormone was decreased $(\mathrm{P}<0.05)$ in the cocks fed dietary $12 \%$ ALM by $31.0 \%$ than that of control group (Figure 2). And it insignificantly decreased in the cocks fed diets contain 4 and $8 \%$ ALM by 6.8 and $11.1 \%$, respectively as compared to control group. This result may attributed to that cocks fed $12 \%$ Atriplex nummularia leaves meal accomplished the physiological effects of salt retention and excretion by reducing their plasma aldosterone concentration by nearly $50 \%$ of control values (Amal, 2003; Digby, 2007; El-Hawy, 2013; El-Bassiony, 2013 and Abd El-Galil et al., 2014).

Tri-iodothyronine hormone level was decreased in the cocks fed dietary $12 \%$ ALM by $38.7 \%$ as compared with control group (Figure 3). This decrease may attributed to increase water intake and decrease feed intake which lead to hemodilution or increase in the osmotic pressure of body fluids which resulted in decrease thyroid hormones (Ahmed, 1996; Amal, 2003 and 2013; Shaker, 2014 and Abd El-Galil et al., 2014).

\section{IN CONCLUSION,}

under South Sinai conditions, Atriplex nummularia leaves meal could be utilized safety in Sina cocks diet up to $8 \%$ without adverse or serious effects on the semen quality characteristics and some blood constituents.

\section{ACKNOWLEDGEMENTS}

This research is part of a project of "utilization of some agricultural byproducts and desert plants as nonconventional feedstuffs in poultry diets" which is financially supported by Ministry of International Cooperation, Egypt. 
Emam $^{1 *}$, K. R. S.et al.

Table (1): Composition and calculated analysis of the experimental diets.

\begin{tabular}{|c|c|c|c|c|}
\hline \multirow[t]{2}{*}{ Ingredients (\%) } & \multicolumn{4}{|c|}{$\begin{array}{l}\text { Treatments } \\
\text { Atriplex nummularia leaves meal levels }(\%)\end{array}$} \\
\hline & $0 \%$ & $4 \%$ & $8 \%$ & $12 \%$ \\
\hline Atriplex nummularia leaves meal & 0.00 & 4.00 & 8.00 & 12.00 \\
\hline Yellow corn & 62.00 & 60.63 & 60.00 & 58.25 \\
\hline Soybean meal (44 \% CP) & 16.10 & 11.75 & 10.50 & 7.35 \\
\hline Corn gluten meal $(60 \% \mathrm{CP})$ & 4.75 & 6.40 & 6.40 & 8.10 \\
\hline Wheat bran & 6.84 & 7.25 & 5.31 & 4.61 \\
\hline Limestone ground & 2.20 & 2.20 & 2.20 & 2.20 \\
\hline Dicalcium phosphate & 1.70 & 1.70 & 1.70 & 1.70 \\
\hline Vit. and min. premix $*$ & 0.30 & 0.30 & 0.30 & 0.30 \\
\hline Salt & 0.23 & 0.10 & 0.00 & 0.00 \\
\hline Dl- methionine & 0.28 & 0.27 & 0.29 & 0.29 \\
\hline Sand & 5.60 & 5.40 & 5.30 & 5.20 \\
\hline Total & 100 & 100 & 100 & 100 \\
\hline \multicolumn{5}{|l|}{ Calculated values ${ }^{* *}$} \\
\hline Crude protein & 16.11 & 16.10 & 16.04 & 16.13 \\
\hline Crude fiber & 3.29 & 3.21 & 3.06 & 2.95 \\
\hline Ether extract & 2.81 & 2.85 & 2.91 & 2.99 \\
\hline Ash & 2.37 & 2.80 & 3.39 & 3.89 \\
\hline Calculated values & & & & \\
\hline Metabolizable energy ( $\mathrm{kcal} / \mathrm{kg})$ & 2700 & 2700 & 2700 & 2700 \\
\hline Calcium $(\%)$ & 1.25 & 1.26 & 1.27 & 1.28 \\
\hline Available phosphorus (\%) & 0.41 & 0.41 & 0.41 & 0.41 \\
\hline Methionine (\%) & 0.60 & 0.60 & 0.60 & 0.60 \\
\hline Lysine $(\%)$ & 0.72 & 0.71 & 0.78 & 0.81 \\
\hline Methionine+ Cyc $(\%)$ & 0.87 & 0.88 & 0.88 & 0.82 \\
\hline Cystine & 0.27 & 0.28 & 0.28 & 0.29 \\
\hline
\end{tabular}

* Each $2.5 \mathrm{~kg}$ Vitamins and minerals premix comprises (per ton of feed), Vit. A $10000000 \mathrm{IU}$, Vit. D 2000000 IU, Vit.E I0g, Vit.K 31000 mg, Vit. B 1000 mg, Vit. B $5000 \mathrm{mg}$, Vit. B 6 1.5g, Vit. $B_{12} 10 \mathrm{mg}$, Pantothenic acid $10 \mathrm{~g}$, Niacin 30g, Folic acid 1g, Biotin $50 \mathrm{mg}$, Iron $30 \mathrm{~g}$, Manganese 70g, Choline chlorite 10g, Iodine $300 \mathrm{mg}$, Copper 4g, Zinc 50g and Selenium 100 mg.

** According to NRC (1994) 
Emam $^{1 *}$, K. R. S.et al.

Table (2): Semen quality and testosterone hormone of Sina cocks fed diets contain different levels of Atriplex nummularia leaves meal.

\begin{tabular}{|c|c|c|c|c|c|}
\hline \multirow[t]{2}{*}{ Traits } & \multicolumn{4}{|c|}{$\begin{array}{l}\text { Treatments } \\
\text { Atriplex nummularia leaves meal levels }(\%)\end{array}$} & \multirow[t]{2}{*}{$\pm \mathrm{SE}$} \\
\hline & $0 \%$ & $4 \%$ & $8 \%$ & $12 \%$ & \\
\hline $\mathrm{EV}(\mathrm{ml})$ & $0.45^{\mathrm{a}}$ & $0.36^{\mathrm{a}}$ & $0.37^{\mathrm{a}}$ & $0.22^{\mathrm{b}}$ & 0.05 \\
\hline $\mathrm{SC}\left(\times 10^{6} \mathrm{ml}\right)$ & $750.0^{\mathrm{a}}$ & $724.0^{\mathrm{a}}$ & $696.0^{\mathrm{a}}$ & $558.0^{\mathrm{b}}$ & 47.1 \\
\hline $\operatorname{TSO}\left(\times 10^{6}\right)$ & $337.5^{\mathrm{a}}$ & $260.6^{\mathrm{a}}$ & $257.5^{\mathrm{a}}$ & $122.7^{b}$ & 51.9 \\
\hline SM $(\%)$ & $87.0^{\mathrm{a}}$ & $84.0^{\mathrm{ab}}$ & $81.0^{\mathrm{ab}}$ & $71.0^{\mathrm{b}}$ & 6.6 \\
\hline TMS $\left(\times 10^{6}\right)$ & $293.6^{\mathrm{a}}$ & $218.9^{\mathrm{a}}$ & $208.5^{\mathrm{ab}}$ & $87.1^{\mathrm{b}}$ & 52.3 \\
\hline $\mathrm{LS}(\%)$ & 84.4 & 81.2 & 82.8 & 80.8 & 2.4 \\
\hline DS $(\%)$ & 16.6 & 18.8 & 18.8 & 19.2 & 2.4 \\
\hline $\mathrm{SA}(\%)$ & 8.6 & 10.2 & 9.2 & 11.6 & 1.4 \\
\hline SQF & $284.8^{\mathrm{a}}$ & $211.6^{\mathrm{a}}$ & $213.2^{\mathrm{a}}$ & $99.1^{\mathrm{b}}$ & 41.3 \\
\hline $\mathrm{pH}$ & $8.1^{\mathrm{a}}$ & $8.0^{\mathrm{a}}$ & $8.1^{\mathrm{a}}$ & $7.9^{\mathrm{b}}$ & 0.03 \\
\hline
\end{tabular}

$\mathrm{EV}=$ ejaculate volume; $\mathrm{SC}=$ sperm concentration; $\mathrm{TSO}=$ total sperm output; $\mathrm{SM}=$ sperm motility; TMS = total motile sperm; LS = live spermatozoa; $\mathrm{DS}=$ dead spermatozoa; $\mathrm{SA}=$ sperm abnormalities; $\mathrm{SQF}=$ semen quality factor; $\mathrm{pH}=$ hydrogen ion; $\mathrm{T}_{2}=$ testosterone hormone.

a, b Means with different superscript among columns are significant differences $(\mathrm{P}<0.05)$.

Table (3): Hematological parameters of Sina cocks fed diets contain different levels of Atriplex nummularia leaves meal (ALM).

\begin{tabular}{|c|c|c|c|c|c|}
\hline \multirow[t]{2}{*}{ Traits } & \multicolumn{4}{|c|}{$\begin{array}{l}\text { Treatments } \\
\text { Atriplex nummularia leaves meal levels (\%) }\end{array}$} & \multirow[t]{2}{*}{$\pm \mathrm{SE}$} \\
\hline & $0 \%$ & $4 \%$ & $8 \%$ & $12 \%$ & \\
\hline $\mathrm{RBC}\left(\times 10^{6}\right)$ & $5.4^{\mathrm{a}}$ & $5.2^{\mathrm{a}}$ & $5.1^{\mathrm{a}}$ & $4.6^{\mathrm{b}}$ & 0.16 \\
\hline $\mathrm{Hb}(\mathrm{g} / \mathrm{dl})$ & $16.2^{\mathrm{a}}$ & $15.7^{\mathrm{ab}}$ & $15.0^{\mathrm{ab}}$ & $14.2^{\mathrm{b}}$ & 0.64 \\
\hline $\mathrm{Ht}(\%)$ & 45.8 & 44.1 & 45.1 & 45.0 & 0.90 \\
\hline MCV (fl) & $84.8^{\mathrm{b}}$ & $84.8^{b}$ & $88.4^{b}$ & $97.8^{\mathrm{a}}$ & 3.4 \\
\hline $\mathrm{MCH}(\mathrm{pg})$ & 30.0 & 30.1 & 29.4 & 30.8 & 2.4 \\
\hline $\mathrm{MCHC}(\%)$ & $35.3^{\mathrm{a}}$ & $35.6^{\mathrm{a}}$ & $33.2^{\mathrm{ab}}$ & $31.5^{\mathrm{b}}$ & 1.6 \\
\hline
\end{tabular}

RBC's = red blood cells; $\mathrm{Hb}=$ hemoglobin; $\mathrm{Ht}=$ hematocrite $\% ; \mathrm{MCV}=$ mean corpuscular volume; $\mathrm{MCH}=$ mean corpuscular hemoglobin; $\mathrm{MCHC}=$ mean corpuscular hemoglobin concentration.

a, b Means with different superscript among columns are significant differences $(\mathrm{P}<0.05)$. 
Atriplex nummularia leaves, hematological parameters, semen quality, Sina cocks.

Table (4): Biochemical parameters of Sina cocks fed diets contain different levels of Atriplex nummularia leaves meal.

\begin{tabular}{|l|l|l|l|l|l|}
\hline \multirow{2}{*}{ Traits } & \multicolumn{4}{l|}{$\begin{array}{l}\text { Treatments } \\
\text { Atriplex nummularia leaves meal levels (\%) }\end{array}$} & \multirow{2}{*}{ \pm SE } \\
\cline { 2 - 5 } & $\mathbf{0 \%}$ & $\mathbf{4 \%}$ & $\mathbf{8 \%}$ & $\mathbf{1 2} \%$ & \\
\hline Total Protein (g/dl) & 5.6 & 5.5 & 4.9 & 4.2 & 0.69 \\
Albumin (g/dl) & $2.8^{\mathrm{a}}$ & $2.4^{\mathrm{ab}}$ & $2.5^{\mathrm{ab}}$ & $2.1^{\mathrm{b}}$ & 0.25 \\
Globulin (g/dl) & 2.4 & 3.1 & 2.4 & 2.1 & 0.63 \\
Cholesterol (mg/dl) & $109.6^{\mathrm{a}}$ & $96.5^{\mathrm{ab}}$ & $97.2^{\mathrm{ab}}$ & $87.7^{\mathrm{b}}$ & 10.6 \\
Triglycerides (mg/dl) & $236.2^{\mathrm{a}}$ & $227.9^{\mathrm{ab}}$ & $197.2^{\mathrm{ab}}$ & $182.7^{\mathrm{b}}$ & 24.7 \\
ALT (I.U./L) & $30.5^{\mathrm{b}}$ & $32.7^{\mathrm{ab}}$ & $33.3^{\mathrm{ab}}$ & $38.6^{\mathrm{a}}$ & 3.3 \\
AST (I.U./L) & $42.7^{\mathrm{b}}$ & $45.6^{\mathrm{ab}}$ & $47.9^{\mathrm{ab}}$ & $53.4^{\mathrm{a}}$ & 4.5 \\
TAC (mM/L) & 0.39 & 0.37 & 0.36 & 034 & 0.02 \\
\hline
\end{tabular}

$\mathrm{ALT}=$ alanine transaminase; $\mathrm{AST}=$ aspartic transaminase TAC $=$ total antioxidant capacity. a, b Means with different superscript among columns are significant differences $(\mathrm{P}<0.05)$.

Table (5): Mineral parameters of Sina cocks fed diets contain different levels of Atriplex nummularia leaves meal.

\begin{tabular}{|l|l|l|l|l|l|}
\hline \multirow{2}{*}{ Traits } & \multicolumn{3}{|l|}{$\begin{array}{l}\text { Treatments } \\
\text { Atriplex nummularia leaves meal levels (\%) }\end{array}$} & \multirow{2}{*}{ \pm SE } \\
\cline { 2 - 5 } & $\mathbf{0 \%}$ & $\mathbf{4} \%$ & $\mathbf{8 \%}$ & $\mathbf{1 2} \%$ & \\
\hline Sodium $(\mathrm{mEq} / \mathrm{l})$ & 122.5 & 120.9 & 115.6 & 119.3 & 6.4 \\
Potassium (mEq/l) & $4.6^{\mathrm{b}}$ & $4.5^{\mathrm{b}}$ & $5.2^{\mathrm{ab}}$ & $5.5^{\mathrm{a}}$ & 0.22 \\
Chloride $(\mathrm{mEq} / \mathrm{l})$ & $61.3^{\mathrm{b}}$ & $64.4^{\mathrm{ab}}$ & $65.2^{\mathrm{ab}}$ & $69.9^{\mathrm{a}}$ & 2.2 \\
Calcium (mg/dl) & $10.6^{\mathrm{b}}$ & $10.0^{\mathrm{b}}$ & $11.7^{\mathrm{b}}$ & $14.2^{\mathrm{a}}$ & 0.67 \\
Phosphorus (mg/dl) & $5.3^{\mathrm{a}}$ & $5.0^{\mathrm{ab}}$ & $4.7^{\mathrm{b}}$ & $4.5^{\mathrm{b}}$ & 0.34 \\
Magnesium (mg/dl) & 2.2 & 2.1 & 2.2 & 2.2 & 0.13 \\
\hline
\end{tabular}

a, b Means with different superscript among columns are significant differences $(\mathrm{P}<0.05)$. 
Emam $^{1 *}$, K. R. S.et al.

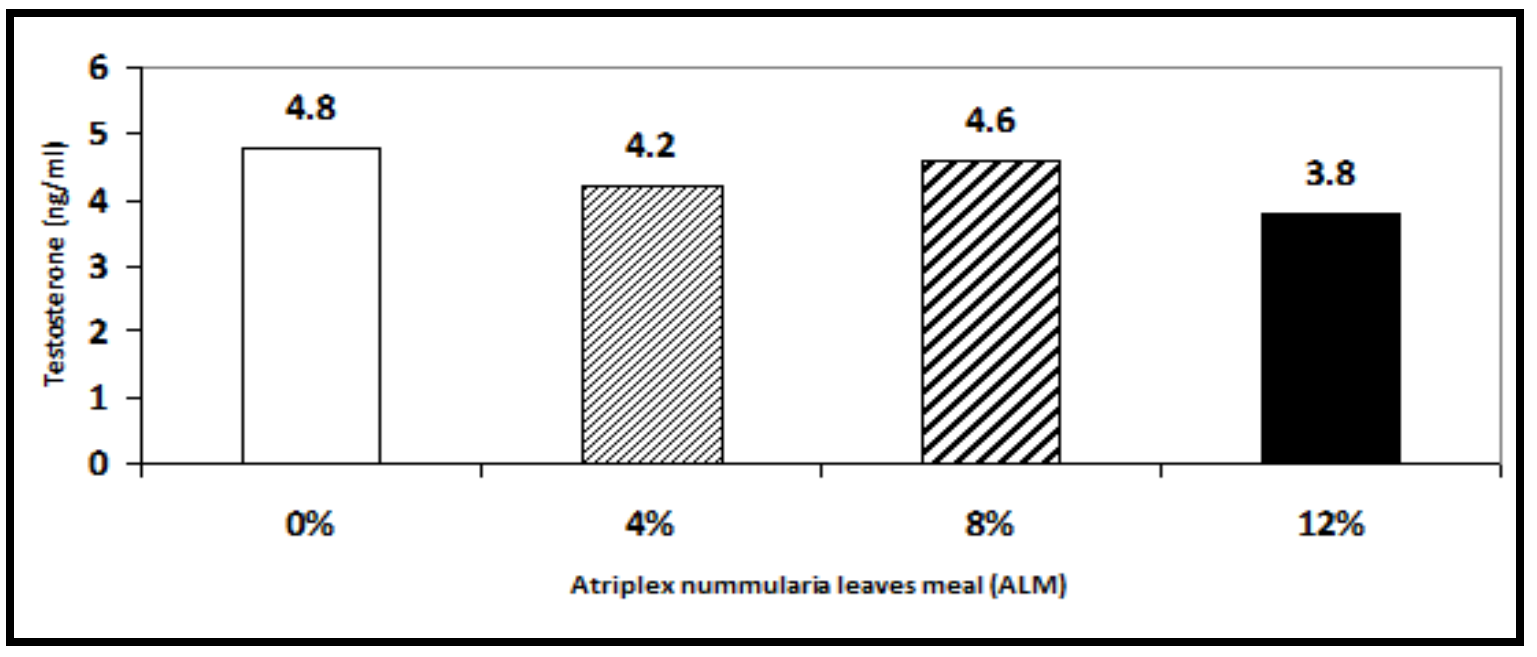

Figure (1): Testosterone hormone of Sina cocks fed diets contain different levels of Atriplex nummularia leaves meal.

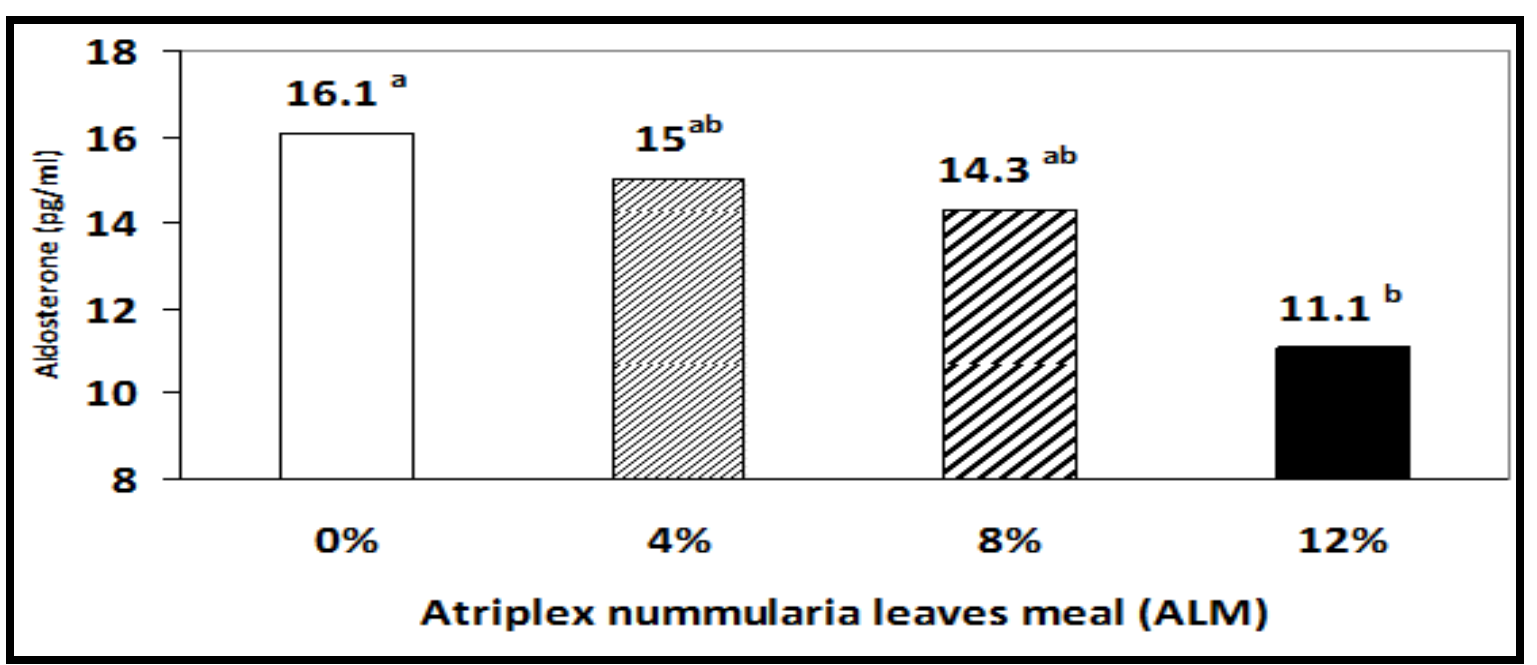

Figure (2): Aldosterone hormone of Sina cocks fed diets contain different levels of Atriplex nummularia leaves meal.

a, b. Means with different superscript in the different columns are significant differences $(\mathrm{P}<0.05)$. 


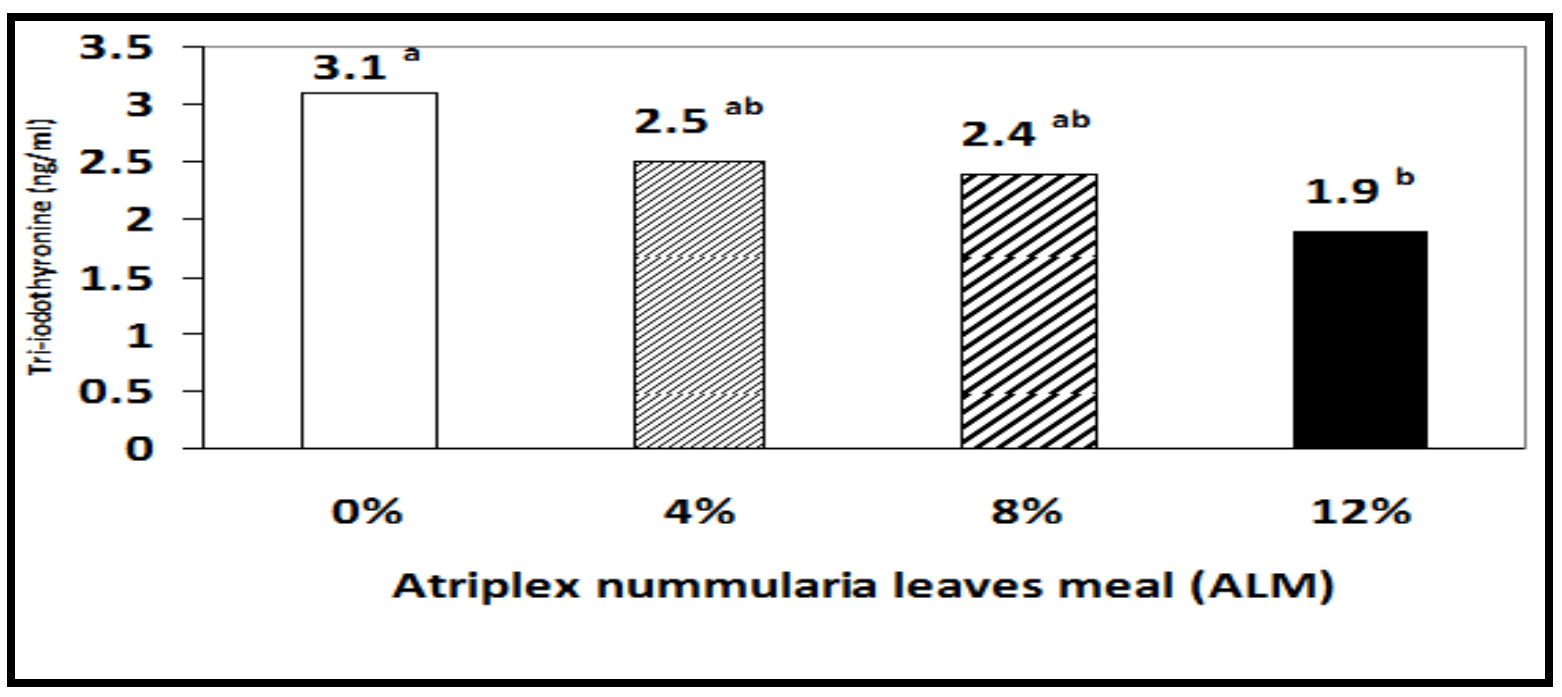

Figure (3): Tri-iodothyronine hormone of Sina cocks fed diets contain different levels of Atriplex nummularia leaves meal.

a, b. Means with different superscript in the different columns are significant differences $(\mathrm{P}<0.05)$ 


\section{REFERENCES}

Abd El Galil, K.; and khider, R. E., 2001. Utilization of Atriplex nummularia in feeding growing rabbits under the desert and newly reclaimed areas. Egypt. Poult. Sci., 21: 53-71.

Abd El-Galil, K.; Morsy, A. S; Emam, K. R. S.; and Amal, M. Hassan, 2014. Physiological and productive performance of Sina laying hens fed Atripex Nummularia leaves meal under Arid Conditions of South Sinai. J. Ame. Sci., 10(5): 161-170.

Ahmed, M. H., 1996. Effect of saline drinking water on productive performance of rabbits. M.Sc. Thesis, Fac. of Agric., Zagazig Univ., Egypt.

Amal, M. Hassan, 2003. Some physiological and productive effects of promoting growth in rabbits drinking natural saline water. Ph.D. Thesis, Fac. Agric. Cairo Univ.

Amal, M. Hassan, 2013. Semen quality and hematology parameters of White leghorn cocks drinking saline water under hot desert conditions. Egypt. Poult. Sci., 33(1): 163-179.

Assad, F .M.; Nassar, A. M.; Hussein, N.; and Abdelmageed, S. M., 1997. Effect of saline water on some water on some biochemical parameters in sheep. Egypt. J. Appl. Sci., 12: 1-13.

Ben Salem, H.; Norman, H. C.; Nefzaoui, A.; Mayberry, D. E.; Pearce, K. L.; and Revell, D. K., 2010. Potential use of oldman saltbush (Atriplex nummularia Lindl.) in sheep and goat feeding. Small Rum. Res., 91: 13-28.

Ben Salem, H.; Sourour Abidi, H. P. S.; Makkar; and Nefzaoui, A., 2005. Wood ash treatment, a cost- effective way to deactivate tannins in Acacai cyanophylla Lindl foliage and to improve digestion by Barbariae sheep.

Anim. Feed Sci. Tech., 122: 93- 108.

Blom, E., 1950. A 1-min live-dead sperm stain by means of eosin-nigrosin. J. Fertil. Steril., 1: 176-177.

Craig, A.M.; Pearson, E.G.; Meyer, C.; and Schmitz, J.A., 1991. Serum liver enzyme and histopathologic changes in calves with chronic and chronicdelayed Senecio jacobaea toxicosis. Am. J. Vet. Res., 52 (12): 1969-1978.

Digby, Serina, N., 2007. High dietary salt during pregnancy in ewes alters the responses of offspring to an oral salt challenge. Ph.D. Thesis, Fac. Agric., Adelaide Univ., Australia.

Duncan, D.B., 1955. Multiple range and multiple F- test, Biometrics, 11:42.

El-Bassiony, M. F., 2013. Productive and reproductive responses of growing Shami goat kids to prolonged saline conditions in South Sinai. Ph.D. Thesis, Fac. Agric., Cairo Univ., Egypt.

El-Hawy, A. S., 2013. Reproductive efficiency of shami goats in salt affected lands in south Sinai. Ph.D. Thesis, Fac. Agric., Ain Shams Univ.

El-Shaer, H. M., 2010. Halophytes and salt-tolerant plants as potential forage for ruminants in the Near East region. Small Ruminant Research, 91(1): 312.

El-Shaer, H. M., 2005. Halophytes as cash crops for animal feeds in arid and semi-arid regions. Proc. International Conference on Biosaline Agriculture \& High Salinity Tolerance, Mugla, Turkey, 9-14 Jan. 2005, pp. 7-15.

El-Shaer, H. M., 2004. Potentiality of halophytes as animal fodder under arid conditions of Egypt. Rangeland and Pasture Rehabilitation in Mediterranean Areas, Cahiers Options Mediterraneenes 62: 369-374. 
Atriplex nummularia leaves, hematological parameters, semen quality, Sina cocks.

Ezzat, W.; Shoeib, M. S.; Kotit, A. H.; Attia, S. A. M.; and Soliman, M. M., 2007. Alleviation of salinity stress using vitamins $\mathrm{c}$ and $\mathrm{e}$ and their relation to growth performance, blood components and some histological changes of broiler chicks. Egypt Poult. Sci. Vol (27) (II): 383-409.

Fayed, Afaf M.; Abeer M. El-Essawy; Eid, E.Y.; Helal H. G.; Ahlam, R. Abdou, and El-Shaer H.M., 2010. Utilization of alfalfa and atriplex for feeding sheep under saline conditions of South Sinai, Egypt. J. Americ. Sci. 6 (12): 1447-1461.

Fayez, M.; Marai, I.; Alnaimy, M.; and Habeeb, A., 1994. Effect of salinity of drinking water on farm animals. In: Ap Dewi I., Axford R.F.E., Fayez M., Marai I., Omed h. (eds): Pollution in Livestock Production Systems. Wallingford, CAB International, 119135.

Hadziosmanovic, A.; Vucemilo, M.; and Venglovsky, J., 1997. Effect of saline drinking water on laying hen productivity. Vet. Med. Czcch., 42, 295-298.

Hassan, A.A., 2009. Effect of some enrichment and nawaz biological treatments on a melioration utilization of atriplex nummularia fed by sheep. Egyptian J. Nut. And Feed. (12): 3 Special Issue: 553-566.

Hussein, N. M.; Assad, F.; AbdelMegeed, S. M.; and Nassar, A. M., 1990. Variation in blood cellulose to drinking salty water in sheep. Egypt. J. Comp. Pathol. Clin. Pathol., 3(1): 55 63.

Ibrahim, S. M. N., 1995. Clinicopathological studies in goats drinking salty water under desert conditions. M. Sc. (clinical pathology), V. Sc. Cairo Univ.
Jaime, S., 2000. Textbook of avian medicine. Chapter 3, Edited by Judith C. H. Harcourt publishers limited, London.

Jarinkovičova, L.; Machal, L.; Machal, J.; Filipčik, R.; Tůmova, E.; and Horsky, R., 2012. Relationship of ejaculate quality and selected biochemical parameters of blood in cockerels of three laying lines. Czech J. Anim. Sci., 57, (8): 370-376.

Kalamah, M. A.; El-Nadi, M. M.; Goher, L. M.; and Soliman, M. M., 2000. Some factors affecting fertility and hatchability using artificial insemination in Norfa chickens. 3rd All Africa Conference on Animal Agric. and 11th Conference of the Egyptian Society of Animal Production, Alex. Egypt, 6-9 November, 597-605.

Kawashti, I. S.; Badawn, M.E.; Mageed, S.M.; and Omer, M.M., 1983. Salt tolerance of desert sheep. 6Effect of saline water administration on intake-urinary and fecal water losses and body water distribution. Desert Inst. Bull., Egypt. 14: 392- 408.

Latimer, K.S.; Mahaffey, E.A.; and Prase, K.W., 2003. Duncan and Prasse's Veterinary Laboratory Medicine: Clinical Pathology. 4th Ed., Iowa State Press, Iowa.

Lessard, P.; Wilson, W.D.; and Olander, H. J., 1986. Clinicopathologic study on horses surviving P. A. (Senecio vulgaris) toxicosis. Anim. J. Vet. Res. 47: 17791780.

Mansoori, B.; and Acamovic, T., 1997. The excretion of minerals from broilers fed tannic acid with and without gelatin. In: Proc. of Spring Meeting of the World Poultry Sci., 2526. 
Emam $^{1 *}$, K. R. S.et al.

Mashaly, M. M.; Hendricks, G. L.; Kalama, M. A.; Gehad, A. E.; Abbas, A. O.; and Patterson, P. H., 2004. Effect of heat stress on production parameters and immune responses of commercial laying hens. Poult. Sci., 83:889-894.

Melrose, D. R.; and Laing, J. A., 1970. The characteristics of normal semen. Chap. 4-Fertility and infertility in the Domestic animals. Ed. by J. A. Laing Bailliere Tindall and Gasssell, London.

Milne, D.B., 1996. Trace elements. In: Tietz Fundamentals of clinical chemistry. Burtis, C.A. and Ashood, E. R. (4th Ed.), 485-496.

Morsy, A.S.; Mona, M. Hassan, and Amal, M. Hassan., 2012. Effect of natural saline drinking water on Productive and physiological performance of laying hens under heat stress conditions. Egypt Poult. Sci. Vol. (32) (III): 561-578.

NRC., 1994. Nutrient Requirements of Poultry. $9^{\text {th }}$ edition. National Academic Press. Washington, D.C.

Peters, S. O.; Omidiji, E. A.; Ikeobi, C. O. N.; Ozoje, M. O.; and Adebambo, O. A., 2004. Effect of Naked Neck and frizzled Genes on egg trait, fertility and hatchability in local chicken. In: Self sufficiency of Animal Protein in Nigeria. Proceeding of the 9th Annual conference of Animal Sci. Association Nig. Ebonyi State University. Nigeria September 13th -16th , pp: 262-264.

Romero, M.J.; Madrid, J.; Hernandez, F.; and Ceron, J.J., 2000. Digestibility and voluntary intake of Vine leaves (Vitisvinifera L.) by sheep. Small Ruminant Res. 38: 191195.
Saacke, R. G.; Dalton J. C.; Nadir S.; Nebel R. L.; and Bame J. H., 2000. Relationship of seminal traits and insemination time to fertilization rate and embryo quality. Animal Reproduction Science, 60, 663-667.

SAS., Institute, 2004. SAS User's Guide: Statistics. Release 9.1. SAS Institute Inc., Cary, NC.

Shaker, Y.M., 2014. Live body weight changes and physiological performance of Barki sheep fed salt tolerant fodder crops under the arid conditions of Southern Sinai, Egypt. J. Am. Sci. 10 (2s): 78-88.

Shaker, Y.M.; Ibrahim, N.H.; Younis, F.E.; and El-Shaer, H.M., 2014. Effect of feeding some salt tolerant fodder shrubs mixture on physiological performance of Shami goats in Southern Sinai, Egypt. J. Am. Sci. 10 (2s): 66-77.

Shawket, S.M.; and Ibrahim, A.H., 2013. Impact of long-term feeding Atriplex (saltbush) on camel's milk production efficiency under arid conditions. Egyptian Journal of Nutrition and Feeds 16 (2) Special Issue: $149-158$.

Sturkie, P. D., 1986. Body temperature. In: Avian Physiology, 2nd ed. Comstock publishing Associates, Division of Cornell University press. Ithaca. New York, pp. 225-230.

Underwood, E.J.; and Suttle, N.F., 1999. The mineral nutrition of livestock. $3^{\text {rd }}$ Edition. Chapter 1. New York, USA. 


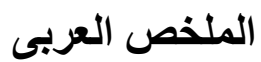

$$
\begin{aligned}
& \text { جودة السائل المنوى وصفات الدم لايوك دجاج سينا المغذاة على مسحوق اوراق نبات } \\
& \text { القطف تحث الظروف الصحمر الصاوية }
\end{aligned}
$$

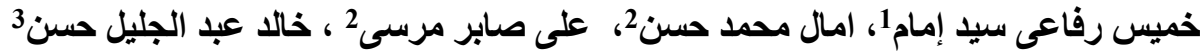

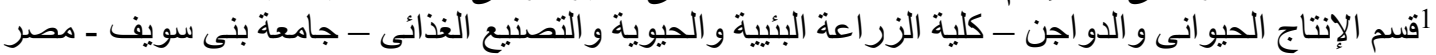

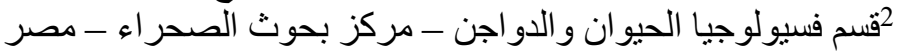

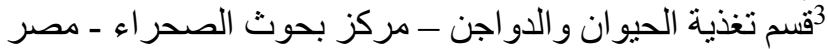

يهدف البحث إلى دراسة تأثثر استخدام مستويات مختلفة من مسحوق أوراق نبات القطف على جودة السائل المنوى

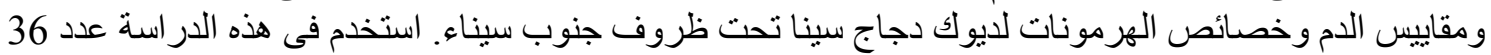

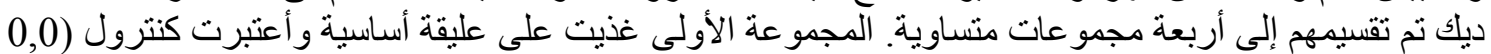

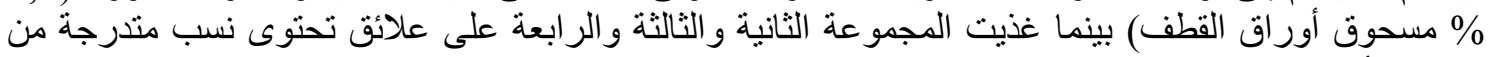

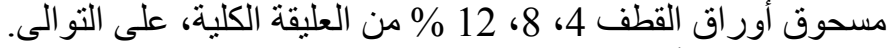

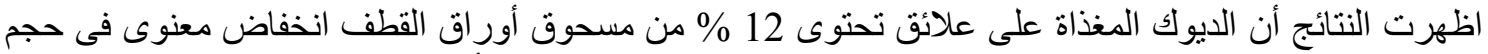

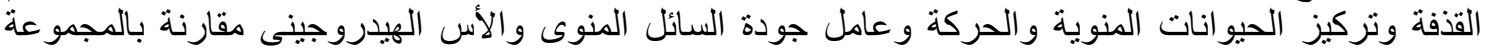

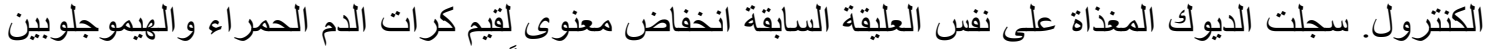

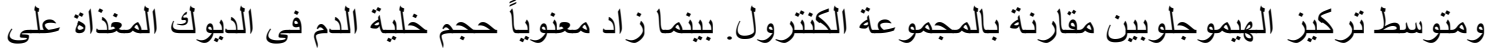

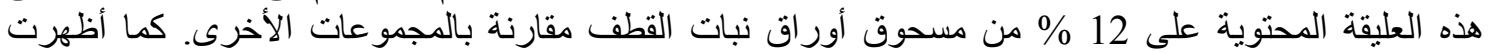

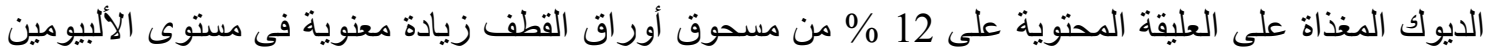

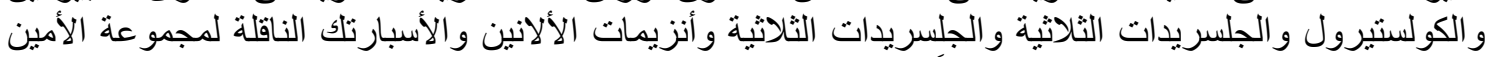

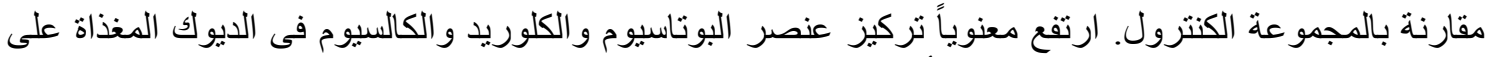

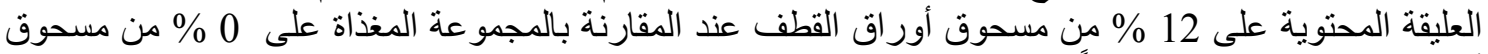

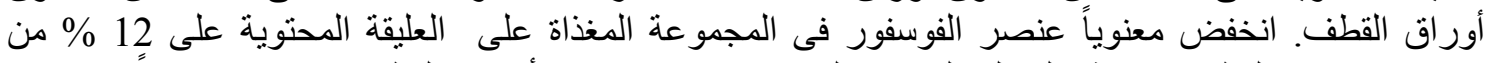

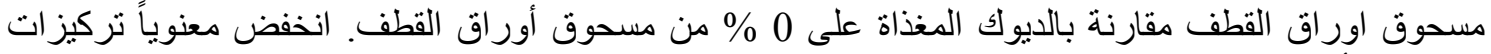
هرمون الألدوسترون والثيرونين ثلاثى اليود فى الديوك المغذاة على العليقة المحتوية على 12 \% من مسحوق أور اق القطف مقارنة بالمجمو عة الكنة الكنترول.

تخلص الدراسة إلى أنه تحت ظروف الجن جنوب سيناء يمكن إستخدام مسحوق اوراق القطف بأمان في عليقة ديوك

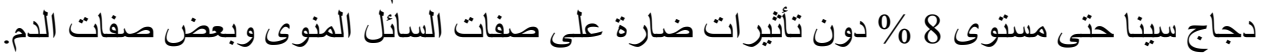

